\title{
The Practicality of Using a Smartphone as a Sound Level Meter
}

\author{
By: \\ Donny Hong ${ }^{1}$, Helen Heacock ${ }^{2}$, Fred Shaw ${ }^{3}$ \\ B.Tech in Environmental Health (Public health Inspection) \\ British Columbia Institute of Technology, 2017
}

\begin{abstract}
PROJECT SUBMITTED IN PARTIAL FULFILLMENT OF THE REQUIREMENTS FOR THE DEGREE OF

Bachelor of Technology in Environmental Health
\end{abstract}

(C) Donny Hong

\section{BRITISH COLUMBIA INSTITUTE OF TECHNOLOGY}

April 2017

\begin{abstract}
All rights reserved. No part of this work covered by the copyright hereon may be reproduced or used in any form or by any means graphics, electronic, or mechanical including photocopying, recording, taping, or information storage and retrieval systems - without written permission of the author.
\end{abstract}

1. Lead Author, B.Tech Student, School of Health Sciences, British Columbia Institute of Technology, 3700 Willingdon Ave, Burnaby, BC V5G3H2

2. Supervisor, School of Health Sciences, British Columbia Institute of Technology, 3700 Willingdon Ave, Burnaby, BC V5G3H2

3. Contributor, School of Health Sciences, British Columbia Institute of Technology, 3700 Willingdon Ave, Burnaby, BC V5G3H2 
"The views expressed in this paper are those of the author and do not necessarily reflect the official policy, position or views of BCIT, the Environmental Health Program or its faculty." 


\begin{abstract}
Background \& Purpose: Sound is of vital importance for human life, it is one of the main forms of communication between people. However, sound that is a nuisance to others is considered noise. Too much noise can be disruptive and affects one's enjoyment of life and can lead to ill health effects. In some municipalities, bylaw officers or Environmental Health Officers (EHOs) are tasked with enforcing the local noise bylaw. "Sound Level Meters" (SLM) are certified instruments enforcement officers use to accurately measure sound. However, accurate SLMs can be bulky and expensive. In this technological society, almost everyone has some type of smart phone capable of installing applications (apps) that mimic SLMs. The purpose of this project was to determine the accuracy of phone SLM apps compared to real SLMs.
\end{abstract}

Method: Three Android \& three iOS SLM apps were downloaded from the internet and installed on two Android and one iOS smartphone. The sound source was computer generated white noise. A type 1 SLM was used to set the white noise to three different sound levels, $80 \mathrm{db}, 65 \mathrm{~dB}$, $\& 50 \mathrm{~dB}$. Each Android and iOS smartphone measured the white noise at each sound level utilizing the three different SLM apps. Results were analyzed between the different apps and smartphones. The MANOVA and ANOVA statistical tests were used to analyze the data.

Results: All MANOVA and ANOVA tests showed statistically differences between the apps and the SLM ( $p=0.00000)$. The power for all MANOVA tests was $100 \%$, therefore there is confidence that the findings reflect the truth and there really is a difference between the different applications, smartphones, and interaction of applications and smartphones. Therefore, the smartphone/app combination tested were not able to replicate the noise level as measured by the SLM.

Conclusion: It can be concluded that any individual Android SLM application can have significantly different mean decibels values across different Android smartphones. Different Android smartphones can also have significantly different means decibels across different Android applications. Results for iOS smartphones can only indicate significant mean decibels across the different SLM applications. Therefore, it is not recommended that smartphones with sound level measuring apps be used in place of SLMs.

Keywords: Sound Level Meter, Smartphone, Applications, Android, iOS 


\section{Literature Review}

\subsection{Introduction}

The ability for humans to hear sounds has been, and still is today, critical for survival and adaptation of modern society. However, unwanted sound or noise can be disruptive and greatly affects our enjoyment of life. Most countries in the world recognize the importance of minimizing noise and therefore, introduced laws prohibiting the making of specific noises and limiting how loud noise can be. These laws are usually enforced by a public health or occupational health and safety officer. Officers use "Sound Level Meters" (SLMs) which are instruments to accurately measure sound; however, accurate SLMs can be cost prohibitive and inconvenient to carry around.

A former Environmental Health Officer (EHO) presented a question of whether or not smartphone SLM applications are accurate enough to replace industry grade SLMs. This prompted a review of the current literature on the accuracy of smart phone SLM applications and their practicality when used by professionals.

\subsection{Sound and Units of Measurement}

Oscillation or vibration of an object will transfer energy known as sound waves, these waves are detected by our ears and converted into information which then is sent to the brain (1). Sound is measured in units of decibels $(\mathrm{dB})$, only the intensity of the sound waves are measured. Sounds that are perceived as loud, will have more intense sound waves and higher $\mathrm{dBs}$, viceversa for quieter sounds (1).

\subsection{Public Health Significance}

It is well-established that when humans are exposed to extremely loud noises for long periods of time, hearing loss will occur. Aside from auditory health effects, studies have shown that public exposure to environmental noises cause non-auditory health effects (2). These health effects include sleep disturbance, a decrease in cognitive performance, increased risk of cardiovascular disease, and emotional annoyance (2). Today, many municipalities and cities establish noise bylaws in order to control environmental noises. In some cities, enforcement is delegated to EHOs.

\subsection{Types of Sound Level Meters}

The American National Standards Institution (ANSI) provides a standard for three grades of SLMs, type 0,1 , and 2 . These grades are designated based on the accuracy which allows for specified deviations of measurements (3). Type 0 SLMs are used in laboratory settings as a reference standard. Type 1 SLMs are designed to be very accurate with an allowable deviation of +/$1.5 \mathrm{~dB}$. Type $2 \mathrm{SLMs}$ are designed for general purposes with an allowable deviation of $+/-2.3 \mathrm{~dB}$ (3). A type $2 \mathrm{SLM}$ is considered the minimum standard for most regulations and laws (4).

\subsection{Current Status of Sound Level Meter Smartphone Applications}

According to the Canadian Radio-Television and Telecommunications Commission 
(CRTC) two-thirds of the Canadian population own some type of smart phone (5). These smart phones have the capabilities to measure sound. SLM applications or "apps", can be installed on the phone, the speaker on the phone is used to collect sound and data readout is almost instantaneous. The two most common operating systems for smartphones are Apple iOS and Google Android, there are currently more than 50 SLM apps available for both platforms (6).

\subsection{Smartphone SLM Application Selection Criteria}

In order for SLM apps to be used in an occupational setting, the app must meet some type of criteria for functionality. Kardous and Shaw (2014) tested only apps that met all or most the following four criteria:

1. Slow or fast response recording 2. Time-weighted average (TWA) or Equivalent continuous sound level average (leq)

3. Report data as unweight (C/Z/Flat) or Aweighted

4. $3 \mathrm{~dB}$ or $5 \mathrm{~dB}$ exchange rate

They also considered non-critical features such as calibration adjustment, automatic reporting and sharing. The researchers examined 130 iOS and 62 Android apps against their criteria and shortlisted to 10 and 4 apps respectively (6). Compared to Kardous and Shaw (2014), Nast and his colleagues (2014) only tested iOS apps that met one criteria, an option for $\mathrm{C}$-weighting and A-weighting (7).
It is apparent that many SLM apps out in the market would not be used in an occupational setting simply based on the lack of features. A probable reason is that an app developer would need to invest many hours implementing these features. Another reason could be since the app store is accessible by everyone, developers are targeting the average person who is limited in knowledge about sound measurement.

\section{7 iOS vs Android platforms}

As of 2015, Android and iOS platforms make up $98.2 \%$ of the worldwide smartphone market share (8). Therefore, all studies compared apps between both platforms or solely looked at iOS apps.

According to Kardous and Shaw (2014), out of the ten iOS apps that met their screening criteria, only three apps had a mean difference within $+/-2 \mathrm{~dB}$ of the reference measurement. The deviation applies to both A \& unweighted measurements. Android app measurements were not analyzed due to the high variability of results. They concluded that according to ANSI standards, these apps could meet type 2 SLM accuracy standard and may be considered accurate in specific noise environments (6). Nast and his colleagues (2014) extended the recent work done by Kardous and Shaw (2014) and verified at A-weighted measurements, only one iOS app, SoundMeter by Faber Acoustical performed similarly. But for Cweighted measurements, the researchers observed mean differences of $+/-5-10 \mathrm{~dB}$ for the same apps (7).

Based on these two studies, it seems that almost all SLM apps can be recommended for recreational purposes due to the large $\mathrm{dB}$ 
deviations; with the exception of possibly one iOS app, SoundMeter. The overall limitation between the two studies was the lack of testing devices, Nast and his colleagues (2014) used a single iOS device compared to four iOS and five Android devices from Kardous and Shaw (2014)(6,7). A major gap for both these studies is that they mainly focused on the accuracy between apps but not between different devices.

A more recent study, Murphy and King (2016) examined not only accuracy between apps of the two platforms but also differences in smartphone models. The researchers also had access to one hundred smartphones of various models across six different brands (9). This study covers the gaps and builds on the research of Kardous and Shaw (2014) and Nast and his colleagues (2014). Between the platforms, Murphy and King (2015) discovered that iOS apps performed better than Android apps. Even though some Android apps had similar mean values to the reference, there was high variability making their data questionable. The researchers also found that Android apps are more likely to under report levels compared to iOS apps (9). Similarly, Keene and her colleagues (2013) noticed that every Android app they tested was under-reporting the true sound level (10). From a public health perspective, this issue can be a health hazard as potentially dangerous levels of noise can be under reported and thereby corrective action will not be taken (9). Interestingly enough, Murphy and King (2016) found significant differences between different brands of smartphones utilizing the same apps. Android devices from HTC Corporation and
Samsung performed better than Apple devices (9).

\subsection{External Microphone}

As a follow up study to Kardous and Shaw (2014), Kardous and Shaw (2016) examined the accuracy of four SLM iOS apps while devices were attached with an external microphone. They compared a cheaply priced microphone and a type 2 SLM certified microphone (11). The researchers found that there were no significant differences between the microphones and the sound levels from the apps. Even though this study appears to have promising results, the testing was limited in terms of only using six iOS devices and four apps (11).

\subsection{Literature Review Summary}

This literature review summarizes the current research on assessing the accuracy of SLM apps and their practicality for professional use. Evidence suggest that between iOS and Android platforms, iOS apps are more accurate and precise. Android apps have been shown to be imprecise and known for under reporting sound levels. There is also evidence to conclude that the accuracy of sound level measurements is not solely dependent on the actual app, but the specific smartphone may be a significant factor. The use of an external microphone may increase precision and accuracy, but a more comprehensive study is needed across a wide range of devices and apps. The existing research suggest SLM apps are still unlikely to be used in an occupational or public health environment, but technology is rapidly evolving as new smartphones and applications are released every year. 


\section{Methods and Materials}

\subsection{Purpose and Hypothesis}

The purpose of this study was to determine whether a smartphone is accurate enough to meet the specifications of a type 1 sound level meter (SLM). This study also examined the differences between Android and iOS applications.

$\mathrm{H}_{0}$ - There is no statistically significant difference in the means of decibels between SLM applications and a type 1 SLM

$\mathrm{H}_{\mathrm{a}}$ - There is a statistically significant difference in at least one mean of decibels between SLM applications and a type 1 SLM

\subsection{Description of Materials}

Table 1 - List of Equipment Used

\begin{tabular}{|l|l|}
\hline Equipment & Description \\
\hline $\begin{array}{l}\text { Computer with } \\
\text { Windows operating } \\
\text { system \& internet }\end{array}$ & $\begin{array}{l}\text { Needed to run } \\
\text { statistical analysis } \\
\text { programs and produce } \\
\text { white noise. }\end{array}$ \\
\hline $\begin{array}{l}\text { NCSS 11 by NCSS, } \\
\text { LLC }\end{array}$ & $\begin{array}{l}\text { The statistical analysis } \\
\text { program to analyze } \\
\text { data after collection. }\end{array}$ \\
\hline Microsoft Excel & $\begin{array}{l}\text { A spreadsheet } \\
\text { program to store and } \\
\text { organize recorded } \\
\text { data. }\end{array}$ \\
\hline Huawei P8 & $\begin{array}{l}\text { Android smartphone } \\
\text { released in 2015 to run } \\
\text { SLM applications. }\end{array}$ \\
\hline
\end{tabular}

\begin{tabular}{|c|c|}
\hline $\begin{array}{l}\text { Samsung } \\
\text { Note } 3\end{array}$ & $\begin{array}{l}\text { Android smartphone } \\
\text { released in } 2012 \text { to run } \\
\text { SLM applications. }\end{array}$ \\
\hline Apple iPhone 5s & $\begin{array}{l}\text { iOS smartphone } \\
\text { released in } 2013 \text { to run } \\
\text { SLM applications. }\end{array}$ \\
\hline $\begin{array}{l}\text { Sound Meter version } \\
1.6 .8 \text { developed by } \\
\text { Smart Tools co. }\end{array}$ & $\begin{array}{lr}\text { Free Android SLM } \\
\text { application } & \text { for } \\
\text { measuring sound. } & \end{array}$ \\
\hline $\begin{array}{l}\text { Noise Meter version } \\
3.8 .3 \text {, developed by } \\
\text { JINASYS }\end{array}$ & $\begin{array}{lr}\text { Free Android SLM } \\
\text { application } \\
\text { measuring sound. }\end{array}$ \\
\hline $\begin{array}{l}\text { Decibel Pro version } \\
1.6 \text {, developed by } \\
\text { BSB Mobile } \\
\text { Solutions Tools }\end{array}$ & $\begin{array}{l}\text { Paid (\$4.67) Android } \\
\text { SLM application for } \\
\text { measuring sound. }\end{array}$ \\
\hline $\begin{array}{lrr}\text { Decibel } & 10^{\text {th }}: & \text { Pro } \\
\text { Noise } & \text { Meter, } \\
\text { developed } & \text { by } \\
\text { SkyPaw Co. Ltd } & \end{array}$ & $\begin{array}{lr}\text { Free iOS SLM } \\
\text { application } \\
\text { measuring sound. }\end{array}$ \\
\hline $\begin{array}{l}\text { NIOSH } \\
\text { developed by EA, } \\
\text { LAB }\end{array}$ & $\begin{array}{lr}\text { Free iOS } & \text { SLM } \\
\text { application } & \text { for } \\
\text { measuring sound. } & \end{array}$ \\
\hline $\begin{array}{l}\operatorname{logSPL}, \quad \text { developed } \\
\text { by Fabien Lefebvre }\end{array}$ & $\begin{array}{l}\text { Paid (\$2.79) iOS SLM } \\
\text { application for } \\
\text { measuring sound. }\end{array}$ \\
\hline $\begin{array}{l}\text { Type 1 Sound Level } \\
\text { meter (SLM) } \\
\text { Model - Question } \\
\text { Technologies } 1900\end{array}$ & $\begin{array}{l}\text { A sound level meter } \\
\text { that is certified to be } \\
\text { type } 1 .\end{array}$ \\
\hline $\begin{array}{ll}\text { Sound } & \text { Level } \\
\text { Calibrator } & \end{array}$ & $\begin{array}{l}\text { A calibrator used to } \\
\text { calibrate the sound } \\
\text { level meter. }\end{array}$ \\
\hline & $\begin{array}{l}\text { To attach the sound } \\
\text { level meter and adjust } \\
\text { the equipment's } \\
\text { height. }\end{array}$ \\
\hline Measuring Tape & $\begin{array}{l}\text { To correctly measure } \\
\text { the appropriate height } \\
\text { required for the } \\
\text { smartphone and sound } \\
\text { level meter } \\
\text { measurement. }\end{array}$ \\
\hline Speakers & $\begin{array}{l}\text { To continuously play } \\
\text { white noise at various } \\
\text { sound levels. }\end{array}$ \\
\hline
\end{tabular}

\subsection{Description of Standard Method}


Sound was created digitally using a white noise generator and played continuously through external speakers. Sound level was adjusted using a SLM and measured at three levels, $50 \mathrm{dBA}, 65 \mathrm{dBA}$ and 80dBA. Both the SLM and smartphones were at a height of $1.2 \mathrm{~m}$ and placed the same distance away from the noise source. A measuring tape was used to verify these distances. Any obstructions between the noise source and measurement devices was removed or minimized. The experiment was completed in a small lab at the BCIT Burnaby campus in SW1-1230. The ambient sound levels in the lab prior to the experiment were measured to be $44.3 \mathrm{dBA}$ using the type 1 SLM.

The SLM and phone applications was set to the A-network and slow response rate. The range setting of the SLM was changed so that the measured sound level was in the middle. Starting with the "Sound Meter" application on the Samsung smartphone, sound measurements were taken continuously at $50 \mathrm{dBA}$ white noise level. At an interval of every 5 seconds, a sound reading was recorded in a lab book until 30 readings were recorded. This process was then repeated with the "Noise Meter" and "Decibel Pro" applications on the same Samsung device. The Huawei smartphone then repeated the same procedures with the three exact applications on the $50 \mathrm{dBA}$ white noise level. Following the two Android smartphones, the iPhone measured the 50 dBA white noise level using three different applications, "Decibel 10 $10^{\text {th", "NIOSH }}$ SLM", and "logSPL". The entire process was then repeated with $65 \mathrm{~dB}$ and $80 \mathrm{~dB}$ sound levels with all three smartphones.
Once the data had been collected, it was transferred digitally onto an Excel spreadsheet. Data was be divided between three spreadsheets based on the three sound levels. NCSS 11 was then used to analyze the data.

\subsection{Inclusion and Exclusion Criteria}

Currently, there are more than 50 SLM applications available for the Android and iOS platform, therefore chosen applications must meet several criteria (6). The first criteria is the ability for reported sound levels to be A-weighted. This is important because A-weighting filters out sounds that are not audible to human ears (14). The second criteria is reported sound levels must be in units of decibels. The final criteria is the application must be free or cost less than five dollars. This study is budget restricted, which limited the applications available for study. The criteria for the applications to have manual calibration was not included because to simulate a real world application, users would not carry around sound calibration equipment.

\section{Statistical Analysis and Results}

\subsection{Statistical Package}

This study used the statistical software NCSS 11 to analyze collected data for inferential statistics (15). Microsoft Excel's Data Analysis tool was only be used to analyze descriptive statistics (16).

\subsection{Data Description}


The SLM and smartphone applications measured sound levels in units of Aweighted decibels (dBA). Decibels are considered numeric data, more specifically, continuous data.

All sound level readings were recorded in a lab record book during the experiment, data was then digitally transferred to an Excel spreadsheet.

\subsection{Descriptive Statistics}

In regards to Table 2 , the expected mean decibel value should approximate the 80 dBA standard, but the mean decibel from all SLM apps has large deviations. The only exception is the "Decibel Pro" app from the Samsung smartphone that has a mean decibel value of $80.52 \mathrm{dBA}$. It is an interesting observation that all apps from the Huawei smartphone consistently under report decibel mean values. The iPhone mean decibel value for the "Decibel $10^{\text {th }}$ " and "Log SLM" apps appears to be $+3-4$ dBA deviation from the standard, while the "NIOSH SLM" has a -5 dBA deviation.

Table 2 - Descriptive Analysis of Decibel Levels by Smartphone and App for 80 dBA

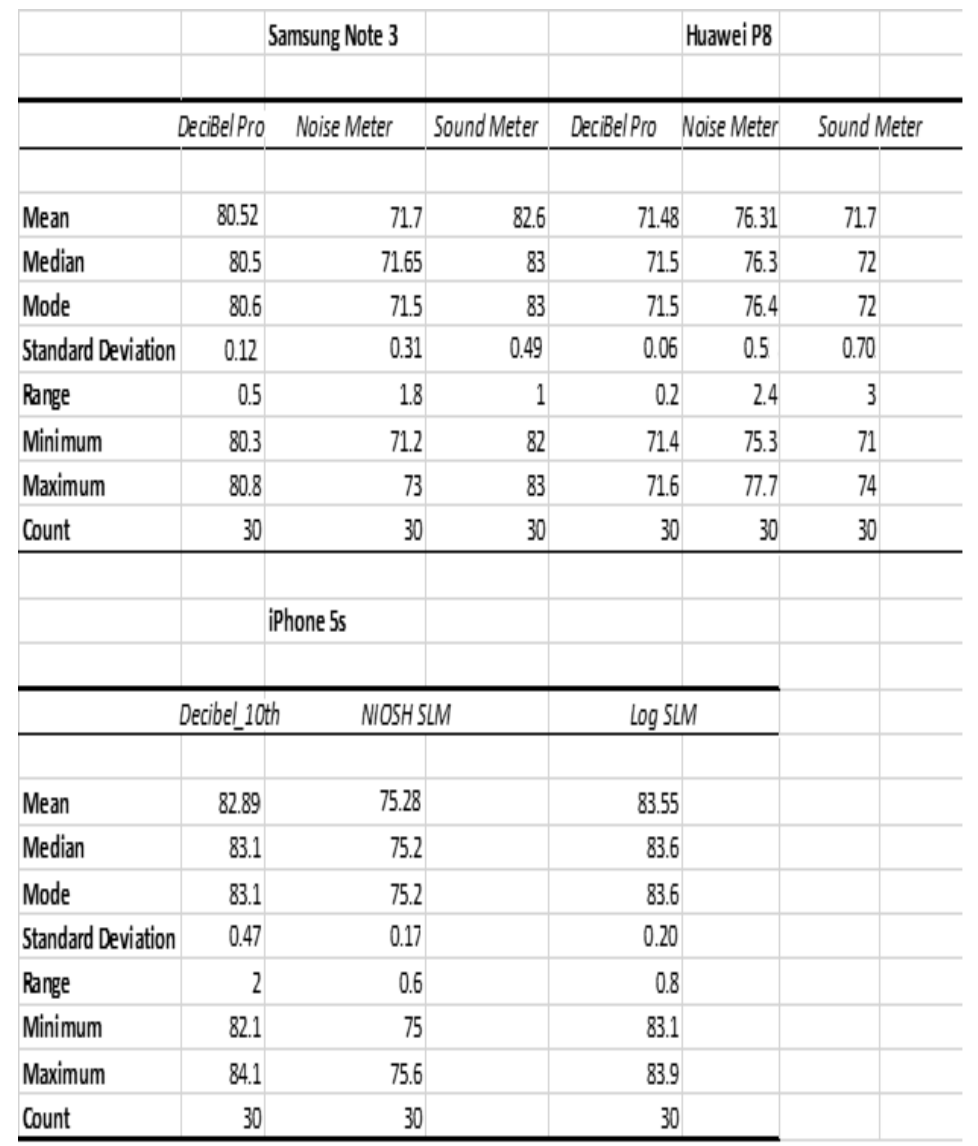

Referring to Table 3, the expected mean decibel values should be close to the $65 \mathrm{dBA}$ standard. The apps from the Samsung smartphone performed the best, as observed previously, the "Decibel Pro" app performed the best with a mean decibel value of 65.88 . As discussed earlier, the apps from the Huawei smartphone record consistently lower mean decibel levels compared to the standard with deviations of - 5-9 dBA. All apps from the iPhone have higher decibel mean values with the "NIOSH SLM" app performing the best with a +2 deviation from the standard. However, the standard deviation is quite high, suggesting that this SLM app could be unreliable.

Table 3 - Descriptive Analysis of Decibel Levels by Smartphone and App for 65 dBA 


\begin{tabular}{|c|c|c|c|c|c|c|}
\hline & \multicolumn{3}{|c|}{ Samsung Note 3} & \multicolumn{3}{|c|}{ Huawei P8 } \\
\hline & DeciBel Pro & Noise Meter & Sound Meter & DeciBel Pro & Noise Meter & Sound Meter \\
\hline Mean & 65.88 & 62.93 & 67.96 & 56.65 & 60.25 & 56.2 \\
\hline Median & 66.15 & 62.9 & 68 & 56.6 & 60 & 56 \\
\hline Mode & 66.3 & 62.9 & 68 & 56.6 & 60 & 56 \\
\hline Standard Deviation & 0.89 & 0.32 & 0.71 & 0.23 & 1.15 & 0.71 \\
\hline Range & 3.4 & 15 & 2 & 0.8 & 4.1 & 2 \\
\hline Minimum & 63.3 & 62.4 & 67 & 56.3 & 58.3 & 55 \\
\hline Maximum & 66.7 & 63.9 & 69 & 57.1 & 62.4 & 57 \\
\hline Count & 30 & 30 & 30 & 30 & 30 & 30 \\
\hline
\end{tabular}

\begin{tabular}{|c|c|c|c|c|c|}
\hline & \multicolumn{2}{|r|}{ Samsung Note3 } & \multicolumn{3}{|c|}{ Huawei P8 } \\
\hline & DeciBel Pro & Noise Meter Sound Meter & \multicolumn{3}{|c|}{ DecíBel Pro Noise Meter Sound Meter } \\
\hline Mean & 50.24 & $\begin{array}{l}4 \quad 48.46 \quad 54.3 \\
\end{array}$ & 43.78 & 46.31 & 45.66 \\
\hline Median & 50.15 & 484 & 43.9 & 46.2 & 46 \\
\hline Mode & 50.5 & 483 & 43.9 & 45.5 & 46 \\
\hline Standard Deviation & 0.68 & 0.26 & 0.51 & 117 & 0.71 \\
\hline Range & 3.6 & 1 & 18 & 6.5 & 3 \\
\hline Minimum & 48.9 & 481 & 42.8 & 45.2 & 44 \\
\hline Maximum & 52.5 & 49.1 & 44.6 & 517 & 47 \\
\hline \multirow[t]{3}{*}{ Count } & 30 & 30 & 30 & 30 & 30 \\
\hline & \multicolumn{2}{|r|}{ iphone 5s } & & & \\
\hline & Decibel_ath & NIOSHSLM & logSLM & & \\
\hline Mean & 5.58 & 45.73 & 55.25 & & \\
\hline Median & 57.5 & 45.7 & 55.25 & & \\
\hline Mode & 57.4 & 45.8 & 55.3 & & \\
\hline Standard Deviation & 032 & 0.06 & 0.11 & & \\
\hline Pange & 1.3 & 0.2 & 0.4 & & \\
\hline Minimum & 57.1 & 45.6 & 55.1 & & \\
\hline Maximum & 58.4 & 45.8 & 55.5 & & \\
\hline Count & 30 & 30 & 30 & & \\
\hline
\end{tabular}

Regarding Table 4, the expected mean decibel values should approximate the 50 dBA standard. The same pattern is shown with the SLM apps from the Huawei smartphones, all mean decibels are drastically lower compared to the standard. Once again, the "Decibel Pro" SLM app from the Samsung smartphone has a mean decibel value of $50.24 \mathrm{dBA}$ which is extremely close to the $50 \mathrm{dBA}$ standard. The iPhone apps underperformed with large fluctuations compared to the standard.

Table 4 - Descriptive Analysis of Decibel Levels by Smartphone and App for 50 dBA

\subsection{Inferential Statistics}

This study examines two hypotheses because there are two factor variables and one response variable. The multivariate analysis of variance (MANOVA) test is the most suitable since it tests hypotheses on the effect of the response variable on two or more factor variables (17). The factor variables are the type of smartphones and applications, while the response variable is decibels. Both hypotheses are tested for each sound level (50 dBA, $65 \mathrm{dBA}, 80 \mathrm{dBA}$ ). Apple smartphones and $\mathrm{iOS}$ applications are not included in this test because the applications used between the two smartphones are different.

The first null hypothesis is that there is no differences between mean decibels and the types of Android smartphone. The alternative hypothesis would be that mean decibels are statistically significantly 
different between the types of Android smartphones.

The second null hypothesis is that there is no differences between mean decibels and the Android SLM applications. The alternative hypothesis would be that mean decibels are statistically significant different between Android SLM applications.

This study also utilizes the ANOVA test, specifically to see if differences exists between iOS applications. Separate hypotheses are tested for each sound level (50 dBA, $65 \mathrm{dBA}, 80 \mathrm{dBA})$.

The null hypothesis is that there is no difference in mean decibels between the different iOS applications. The alternative hypothesis is that there is a statistically significant difference in mean decibels between the different iOS applications.

\subsection{Results of Inferential Statistics}

Referring to Table 5 - "MANOVA \& ANOVA Inferential Statistics Results", all MANOVA tests concluded in favour of the alternative hypothesis. Between all sound levels, there is a statistically significant difference in mean decibels between different Android smartphones and SLM applications. The results also indicate that the interaction between the Android smartphones and applications are significant with a p-value of $0.000000 *$. The power for all MANOVA tests is $100 \%$, therefore there is confidence that the findings reflect the truth and there really is a difference between the different applications, smartphones, and interaction of applications and smartphones. The ANOVA tests also concluded in favour of the alternative hypothesis in all three sound levels. Therefore, there is a statistically significant difference in mean decibels between iOS applications. Normality in all ANOVA tests are rejected except in the $65 \mathrm{dBA}$ sound level. 
Table 5 - MANOVA \& ANOVA Inferential Statistics Results

\begin{tabular}{|c|c|c|c|c|c|}
\hline $\mathrm{Ho}$ and $\mathrm{Ha}$ & Test Used & Result & Power & Conclusion & $\begin{array}{l}\text { Post Hoc } \\
\text { Analysis }\end{array}$ \\
\hline $\begin{array}{l}\text { Ho: There is no } \\
\text { differences } \\
\text { between mean } \\
\text { decibels and the } \\
\text { types of Android } \\
\text { smartphone at the } \\
80 \text { dBA sound } \\
\text { level. } \\
\text { Ha: There is a } \\
\text { statistically } \\
\text { significance } \\
\text { difference between } \\
\text { mean decibels and } \\
\text { the types of } \\
\text { Android } \\
\text { smartphone at the } \\
80 \text { dBA sound } \\
\text { level. }\end{array}$ & MANOVA & $\begin{array}{l}\mathrm{P}= \\
0.000000 *\end{array}$ & 1.000000 & $\begin{array}{l}\text { Reject Ho and } \\
\text { conclude there } \\
\text { is a } \\
\text { statistically } \\
\text { significance } \\
\text { difference } \\
\text { between mean } \\
\text { decibels and the } \\
\text { types of } \\
\text { smartphone at } \\
\text { the } 80 \text { dBA } \\
\text { sound level. }\end{array}$ & $\mathrm{N} / \mathrm{A}$ \\
\hline $\begin{array}{l}\text { Ho: There is no } \\
\text { differences } \\
\text { between mean } \\
\text { decibels and the } \\
\text { Android } \\
\text { applications at the } \\
80 \text { dBA sound } \\
\text { level. } \\
\text { Ha: There is a } \\
\text { statistically } \\
\text { significance } \\
\text { difference between } \\
\text { mean decibels and } \\
\text { the Android } \\
\text { applications at the } \\
80 \text { dBA sound } \\
\text { level. }\end{array}$ & MANOVA & $\begin{array}{l}\mathrm{P}= \\
0.000000 *\end{array}$ & 1.000000 & $\begin{array}{l}\text { Reject Ho and } \\
\text { conclude there } \\
\text { is a } \\
\text { statistically } \\
\text { significance } \\
\text { difference } \\
\text { between mean } \\
\text { decibels and the } \\
\text { types of } \\
\text { smartphone at } \\
\text { the } 80 \text { dBA } \\
\text { sound level. }\end{array}$ & $\mathrm{N} / \mathrm{A}$ \\
\hline
\end{tabular}




\begin{tabular}{|c|c|c|c|c|c|}
\hline $\begin{array}{l}\text { Ho: There is no } \\
\text { differences } \\
\text { between mean } \\
\text { decibels and the } \\
\text { types of Android } \\
\text { smartphone at the } \\
65 \text { dBA sound } \\
\text { level. } \\
\text { Ha: There is a } \\
\text { statistically } \\
\text { significance } \\
\text { difference between } \\
\text { mean decibels and } \\
\text { the types of } \\
\text { Android } \\
\text { smartphone at the } \\
65 \text { dBA sound } \\
\text { level. }\end{array}$ & MANOVA & $\begin{array}{l}\mathrm{P}= \\
0.000000 *\end{array}$ & 1.000000 & $\begin{array}{l}\text { Reject Ho and } \\
\text { conclude there } \\
\text { is a } \\
\text { statistically } \\
\text { significance } \\
\text { difference } \\
\text { between mean } \\
\text { decibels and the } \\
\text { types of } \\
\text { smartphone at } \\
\text { the } 65 \text { dBA } \\
\text { sound level. }\end{array}$ & $\mathrm{N} / \mathrm{A}$ \\
\hline $\begin{array}{l}\text { Ho: There is no } \\
\text { differences } \\
\text { between mean } \\
\text { decibels and the } \\
\text { Android } \\
\text { applications at the } \\
65 \text { dBA sound } \\
\text { level. } \\
\text { Ha: There is a } \\
\text { statistically } \\
\text { significance } \\
\text { difference between } \\
\text { mean decibels and } \\
\text { the Android } \\
\text { applications at the } \\
65 \text { dBA sound } \\
\text { level. }\end{array}$ & MANOVA & $\begin{array}{l}\mathrm{P}= \\
0.000000 *\end{array}$ & 1.000000 & $\begin{array}{l}\text { Reject Ho and } \\
\text { conclude there } \\
\text { is a } \\
\text { statistically } \\
\text { significance } \\
\text { difference } \\
\text { between mean } \\
\text { decibels and the } \\
\text { types of } \\
\text { smartphone at } \\
\text { the } 65 \text { dBA } \\
\text { sound level. }\end{array}$ & $\mathrm{N} / \mathrm{A}$ \\
\hline $\begin{array}{l}\text { Ho: There is no } \\
\text { differences } \\
\text { between mean } \\
\text { decibels and the } \\
\text { types of Android }\end{array}$ & MANOVA & $\begin{array}{l}\mathrm{P}= \\
0.000000 *\end{array}$ & 1.000000 & $\begin{array}{l}\text { Reject Ho and } \\
\text { conclude there } \\
\text { is a }\end{array}$ & $\mathrm{N} / \mathrm{A}$ \\
\hline
\end{tabular}




\begin{tabular}{|c|c|c|c|c|c|}
\hline $\begin{array}{l}\text { smartphone at the } \\
50 \text { dBA sound } \\
\text { level. } \\
\text { Ha: There is a } \\
\text { statistically } \\
\text { significance } \\
\text { difference between } \\
\text { mean decibels and } \\
\text { the types of } \\
\text { Android } \\
\text { smartphone at the } \\
50 \text { dBA sound } \\
\text { level. }\end{array}$ & & & & $\begin{array}{l}\text { statistically } \\
\text { significance } \\
\text { difference } \\
\text { between mean } \\
\text { decibels and the } \\
\text { types of } \\
\text { smartphone at } \\
\text { the } 50 \text { dBA } \\
\text { sound level. }\end{array}$ & \\
\hline $\begin{array}{l}\text { Ho: There is no } \\
\text { differences } \\
\text { between mean } \\
\text { decibels and the } \\
\text { Android } \\
\text { applications at the } \\
50 \text { dBA sound } \\
\text { level. } \\
\text { Ha: There is a } \\
\text { statistically } \\
\text { significance } \\
\text { difference between } \\
\text { mean decibels and } \\
\text { the Android } \\
\text { applications at the } \\
50 \text { dBA sound } \\
\text { level. }\end{array}$ & MANOVA & $\begin{array}{l}\mathrm{P}= \\
0.000000 *\end{array}$ & 1.000000 & $\begin{array}{l}\text { Reject Ho and } \\
\text { conclude there } \\
\text { is a } \\
\text { statistically } \\
\text { significance } \\
\text { difference } \\
\text { between mean } \\
\text { decibels and the } \\
\text { types of } \\
\text { smartphone at } \\
\text { the } 50 \text { dBA } \\
\text { sound level. }\end{array}$ & $\mathrm{N} / \mathrm{A}$ \\
\hline $\begin{array}{l}\text { Ho: There is no } \\
\text { difference in mean } \\
\text { decibels between } \\
\text { the different iOS } \\
\text { applications at the } \\
80 \text { dBA sound } \\
\text { level. } \\
\text { Ha: } \text { There is a }\end{array}$ & ANOVA & $\begin{array}{l}\mathrm{P}= \\
0.000000^{*}\end{array}$ & $\mathrm{~N} / \mathrm{A}$ & $\begin{array}{l}\text { Reject Ho and } \\
\text { conclude there } \\
\text { is a } \\
\text { statistically } \\
\text { significance } \\
\text { difference in } \\
\text { mean decibels } \\
\text { between the } \\
\text { different iOS }\end{array}$ & $\begin{array}{l}\text { Tukey-Kramer } \\
\text { Multiple- } \\
\text { Comparison } \\
\text { Test } \\
\text {-Decibel } 10^{\text {th }} \\
\text { differ from } \\
\text { NISOH SLM } \\
\text { and Log SPL }\end{array}$ \\
\hline
\end{tabular}




\begin{tabular}{|c|c|c|c|c|c|}
\hline $\begin{array}{l}\text { statistically } \\
\text { significance } \\
\text { difference in mean } \\
\text { decibels between } \\
\text { the different iOS } \\
\text { applications at the } \\
80 \text { dBA sound } \\
\text { level. }\end{array}$ & & & & $\begin{array}{l}\text { applications at } \\
\text { the } 80 \mathrm{dBA} \\
\text { sound level. }\end{array}$ & $\begin{array}{l}\text { - NIOSH SLM } \\
\text { differ from } \\
\text { Decibel } 10^{\text {th }} \\
\text { and Log SPL } \\
\text { - Log SPL } \\
\text { differ from } \\
\text { Decibel 10 } \\
\text { and NIOSH } \\
\text { SLM }\end{array}$ \\
\hline $\begin{array}{l}\text { Ho: There is no } \\
\text { difference in mean } \\
\text { decibels between } \\
\text { the different iOS } \\
\text { applications at the } \\
65 \text { dBA sound } \\
\text { level. } \\
\text { Ha: There is a } \\
\text { statistically } \\
\text { significance } \\
\text { difference in mean } \\
\text { decibels between } \\
\text { the different iOS } \\
\text { applications at the } \\
65 \text { dBA sound } \\
\text { level. }\end{array}$ & ANOVA & $\begin{array}{l}\mathrm{P}= \\
0.000000^{*}\end{array}$ & 1.000000 & $\begin{array}{l}\text { Reject Ho and } \\
\text { conclude there } \\
\text { is a } \\
\text { statistically } \\
\text { significance } \\
\text { difference in } \\
\text { mean decibels } \\
\text { between the } \\
\text { different iOS } \\
\text { applications at } \\
\text { the } 65 \text { dBA } \\
\text { sound level. }\end{array}$ & $\begin{array}{l}\text { Tukey-Kramer } \\
\text { Multiple- } \\
\text { Comparison } \\
\text { Test } \\
\text {-Decibel } 10^{\text {th }} \\
\text { differ from } \\
\text { NISOH SLM } \\
\text { and Log SPL } \\
\text { - NIOSH SLM } \\
\text { differ from } \\
\text { Decibel } 10^{\text {th }} \\
\text { and Log SPL } \\
\text { - Log SPL } \\
\text { differ from } \\
\text { Decibel } 10^{\text {th }} \\
\text { and NIOSH } \\
\text { SLM }\end{array}$ \\
\hline $\begin{array}{l}\text { Ho: There is no } \\
\text { difference in mean } \\
\text { decibels between } \\
\text { the different iOS } \\
\text { applications at the } \\
50 \text { dBA sound } \\
\text { level. } \\
\text { Ha: There is a } \\
\text { statistically } \\
\text { significance } \\
\text { difference in mean } \\
\text { decibels between } \\
\text { the different iOS } \\
\text { applications at the }\end{array}$ & ANOVA & $\begin{array}{l}\mathrm{P}= \\
0.000000^{*}\end{array}$ & $\mathrm{~N} / \mathrm{A}$ & $\begin{array}{l}\text { Reject Ho and } \\
\text { conclude there } \\
\text { is a } \\
\text { statistically } \\
\text { significance } \\
\text { difference in } \\
\text { mean decibels } \\
\text { between the } \\
\text { different iOS } \\
\text { applications at } \\
\text { the } 50 \text { dBA } \\
\text { sound level. }\end{array}$ & $\begin{array}{l}\text { Tukey-Kramer } \\
\text { Multiple- } \\
\text { Comparison } \\
\text { Test } \\
\text {-Decibel } 10^{\text {th }} \\
\text { differ from } \\
\text { NISOH SLM } \\
\text { and Log SPL } \\
\text { - NIOSH SLM } \\
\text { differ from } \\
\text { Decibel } 10^{\text {th }} \\
\text { and Log SPL }\end{array}$ \\
\hline
\end{tabular}




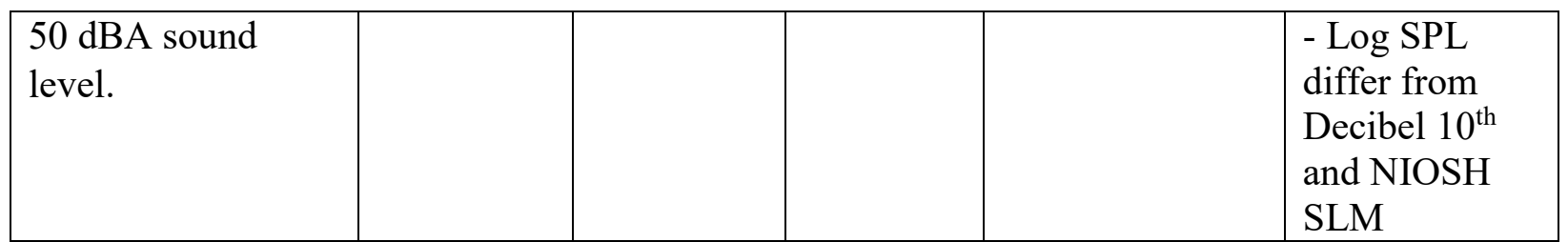




\section{Discussion}

Results of the three different Android smartphones and Android sound level meter (SLM) applications showed that there was a statistically significant difference among all tested sound levels (50 dBA, $65 \mathrm{dBA}, 80$ dBA). Although all tests were statistically significant, the results cannot provide a definitive conclusion on the performance of the SLM application or smartphone. However, they provide observations that should be explored in future studies.

All three Android SLM applications tested under the Huawei P8 smartphone consistently underreported mean sound levels when comparing to the true sound levels ( -4 to -8 dBA deviation). From a public health perspective, this issue can be a health hazard as potentially hazardous levels of sound can be under reported. Keene and her colleagues (2013) also noted that every Android app they tested was also underreporting the true sound level (10). However, the following observation contradicted with the observation made by Keene and her colleagues (2013). Two Android SLM applications (DeciBel Pro and Sound Meter) tested with the Samsung Note 3 smartphone had consistently higher mean sound levels ( +0.5 to $+2.5 \mathrm{dBA})$ when compared to the true sound levels. A possible reason for this contradiction could be that the microphone on the Samsung Note 3 smartphone is superior to the smartphones tested by Keene and her colleagues (2013). This also suggests that between different models of smartphones there are significant differences in sound level measurements on the same exact SLM applications. Murphy and King (2016) found significant differences between different brands of smartphones utilizing the same SLM applications, which agrees with the above observation (9). Murphy and King (2016) also discovered that iOS SLM applications performed better than Android SLM applications resulting from tests of over one hundred smartphones of varying models (9). Based on the one iPhone $5 \mathrm{~s}$ smartphone and three iOS SLM application tested by the author, there is no conclusive evidence to determine if applications from one platform are better than another. However, it appears that the standard deviations for the IOS SLM applications are significantly lower compared to the Android SLM applications.

Overall, the best performing smartphone and SLM application combination is the Samsung Note 3 and "DeciBel Pro". At all tested sound levels there was only a $+/-0.5 \mathrm{dBA}$ deviation from the standard. ANSI standards would consider this performance similar to a type 1 SLM, which allows for deviations of $+/-1.5$ dBA (3).

\section{Limitations}

The main limitation of this study was the lack of resources, in terms of time and budget. Therefore only three smartphones were able to be tested (one iOS and two Android devices). Hence, there is low external validity as there was not a representative amount of smartphones to determine the performance for each platform. The methodology used only three SLM Android applications and three iOS applications. As such, the SLM applications used were not representative for the dozens of SLM applications that exist on the market. If time and resources were unlimited, testing thirty different Android and iOS smartphones across thirty different 
applications would be recommended to have very high external validity.

The main source of error from the methodology was the positioning of the smartphone during sound measurements. Whether the smartphone was placed vertically, horizontally or upright, the positioning of the device can have significant deviations in measured sound levels due to the distance from the microphone to the sound source. The physical size of each smartphone was also different. To minimize this error, a standardized method was used throughout the experiment. The smartphone was placed vertically flat on a hard surface at 1.2 meters above the floor and the microphone was pointed straight at the sound source without any obstructions. To completely eliminate this error and increase internal validity, the experiment would have to be done in a reverberant chamber, as sound levels remain constant in this environment (12). Another source of error is that SLM applications were not designed to meet ANSI standards. The SLM applications were mainly designed for recreational and entertainment purposes, the exception is the NIOSH SLM application for iOS. The microphone on smartphones were also not designed for taking precise sound measurements but for speech purposes. A recommendation is to use an external microphone that is certified for taking sound measurements.

\section{Knowledge Translation}

Due to non-conclusive results and limitations of this study, the observations and recommendations can only be as a starting point for future studies. The results of this study can be reported to health authorities. It is especially important to recommend that traditional SLM is continued to be used until such time that smartphones \& SLM apps are equivalent to SLMs.

There is currently a lack of literature to determine if smartphones and SLM applications can replace dedicated SLMs. However, all the existing literature is less than five years old and more studies in this field are predicted to emerge in the future. There are also new smartphones and SLM applications being developed every year, hence the possibility that a smartphone will be developed for the purpose of sound measurements in the future.

\section{Future Research Suggestions}

- A future study can compare if there is truly a difference in measured sound levels by using an external dedicated microphone for sound measurements such as the Dayton Audio iMM-6 or MICW i436 versus the smartphone's built-in microphone. This study should compare at least one Android and one iOS device, preferably from the latest generation.

- A survey targeting Environmental Health Officers (EHOs) on general SLM knowledge and if there is an interest in SLM applications. EHOs could be asked questions such as the frequency of using a SLM, ability to calibrate without a manual, and interest in using a SLM application from their phones. 


\section{Conclusion}

Based on the inferential statistical results, all tests are statistically significant. There is a statistically significant difference between mean decibel readings of Android smartphones and Android SLM applications at the $50 \mathrm{dBA}, 65 \mathrm{dBA}$, and $80 \mathrm{dBA}$ sound levels. The interaction between smartphone type and application are also statistically significant. The $\mathrm{p}$-value for all tests are $0.000000 *$. The results indicate that any individual Android SLM application can have significantly different mean decibels values across different Android smartphones. The results are the same for individual Android smartphones across different Android SLM applications. The results for iOS smartphones only indicate significant mean decibels across the different SLM applications. The best performing smartphone and SLM app combination from this study was the Samsung Galaxy Note 3 and "DecibelPro". There was a +/- $0.5 \mathrm{dBA}$ deviation at all tested sound levels. 


\section{References}

1. Canadian Centre for Occupational Health and Safety. Noise - Basic Information [Internet]. Noise - Basic Information. 2015 [cited 2016 Oct 20]. Available from:

https://www.ccohs.ca/oshanswers/phys agents/noise basic.html

2. Basner M, Babisch W, Davis A, Brink M, Clark C, Janssen S, et al. Auditory and non-auditory effects of noise on health. Vol. 383, The Lancet. 2014. p. 1325-32.

3. ANSI S1.4: Specifications for Sound Level Meters. 1983 [cited 2016 Oct 21]; Available from: https://aw.resource.org/pub/us/cfr/ibr/002/ansi.s1.4.1983.pdf

4. Canadian Centre for Occupational Health and Safety. Measurement of Workplace Noise [Internet]. 2016 [cited 2016 Oct 21]. Available from:

https://www.ccohs.ca/oshanswers/phys_agents/noise_measurement.html

5. CRTC. Communications Monitoring Report. 2015 [cited 2016 Oct 22]; Available from: http://www.crtc.gc.ca/eng/publications/reports/PolicyMonitoring/2015/cmr.pdf

6. Kardous CA, Shaw PB. No Title [Internet]. NIOSH Science Blog. 2014 [cited 2016 Oct 21 ]. Available from: https://blogs.cdc.gov/niosh-science-blog/2014/04/09/sound-apps/

7. Nast DR, Speer WS, Le Prell CG. Sound level measurements using smartphone "apps": useful or inaccurate? Noise Health [Internet]. 2014;16(72):251-6. Available from:

http://www.ncbi.nlm.nih.gov/pubmed/25209033

8. Smartphone OS Market Share 2016 Q2 [Internet]. 2016 [cited 2016 Oct 22]. Available from: http://www.idc.com/prodserv/smartphone-os-market-share.jsp

9. Murphy E, King EA. Testing the accuracy of smartphones and sound level meter applications for measuring environmental noise. Appl Acoust [Internet]. 2016 May [cited 2016 Oct 23];106:16-22. Available from: http://linkinghub.elsevier.com/retrieve/pii/S0003682X15003667 
10. Keene, K, Merovitz A, Irvine E, Manji N, Everett M, Chung I, Moodie S, et al. Accuracy of Smartphone Sound Level Meter Applications. Can Hear Rep [Internet]. 2013 [cited 2016 Oct 22];8(6):24-8. Available from: http://chr-search.com/pdf/accuracy.pdf

11. Kardous CA, Shaw PB. Evaluation of smartphone sound measurement applications (apps) using external microphones-A follow-up study. J Acoust Soc Am [Internet]. 2016 Oct [cited 2016 Oct 23];140(4):EL327-EL333. Available from:

http://scitation.aip.org/content/asa/journal/jasa/140/4/10.1121/1.4964639

12. Anechoic and Reverberation Chambers [Internet]. 2009 [cited 2016 Nov 20]. Available from: https://val.me.vt.edu/resources/facilities/anechoic-reverberation-chambers

13. Heacock H. Module 5 - Introduction to Statistics. Burnaby; 2016. p. 33-5.

14. Brad W, Leight H. Sound Source: A- and C-Weighted Noise Measurements [Internet]. 2013 [cited 2016 Nov 20]. Available from: http://www.hearforever.org/tools-to-learn/sound-source-aand-c-weighted-noise-measurements

15. NCSS L. No Title [Internet]. Kaysville: NCSS Statistical Software; 2016. Available from: https://www.ncss.com/software/ncss/

16. Use the Analysis ToolPak to perform complex data analysis [Internet]. 2016 [cited 2017 Feb 20]. Available from: https://support.office.com/en-us/article/Use-the-Analysis-ToolPak-toperform-complex-data-analysis-6c67ccf0-f4a9-487c-8dec-bdb5a2cefab6

17. French A, Macedo M, Poulsen J. Multivariate Analysis of Variance (MANOVA) [Internet]. 2016 [cited 2016 Nov 22]. Available from:

http://online.sfsu.edu/efc/classes/biol710/manova/MANOVA 